\title{
Effects of dietary phosphorus and calcium on the intestinal absorption of $\mathrm{Ca}$ in sheep
}

\author{
BY H. M. ABDEL-HAFEEZ, M. MAÑAS-ALMENDROS, R. ROSS \\ AND A. D. CARE \\ Department of Animal Physiology and Nutrition, University of Leeds, LS2 9JT
}

AND D. H. MARSHALL

$M R C$ Mineral Metabolism Research Unit, Leeds General Infirmary, Leeds LSI 3EX

\author{
(Received.12 May 1981-Accepted 24 June 1981)
}

1. Wether sheep were used, some of which were prepared with a Thiry-Vella loop of jejunum. The long-term use of these loops was ensured by regular perfusion with fresh nutrient solution.

2. The net calcium absorption rate from a Thiry-Vella loop of jejunum increased with increasing intraluminal Ca concentration and was increased by the addition of $1 \alpha$-hydroxy-cholecalciferol $(3 \mu \mathrm{g} / \mathrm{l})$ to the loop fluid.

3. When the diet of sheep was changed from one which was normal in $\mathrm{Ca}$ to a diet low in $\mathrm{Ca}$ there was an increase in the efficiency of net $\mathrm{Ca}$ absorption from the jejunal loop. This dietary change was accompanied by an increase in the circulating concentration of 1,25-dihydroxy-cholecalciferol $\left(1,25(\mathrm{OH})_{2} \mathrm{D}_{3}\right)$.

4. An intravenous infusion of the $\mathrm{Ca}$ chelating agent EDTA increased the efficiency of net Ca absorption from the jejunal loop. The use of ${ }^{47} \mathrm{Ca}$ demonstrated that this reflected an increase in the true absorption rate of $\mathrm{Ca}$.

5. Dietary phosphorus deficiency reduced the efficiency of intestinal $\mathrm{Ca}$ absorption and was associated with a reduction in the plasma concentration of $1,25(\mathrm{OH})_{2} \mathrm{D}_{3}$.

It is well recognized that animals adapt to calcium depletion by increasing the efficiency of Ca absorption (Nicolaysen et al. 1953; Morrissey \& Wasserman, 1971; Fox et al. 1977). Also it is well established that animals fed on a low-Ca diet increase the rate at which they absorb this element during the first few days after an adequate $\mathrm{Ca}$ intake has been restored (Braithwaite, 1974, 1975). The mechanism by which these adaptive changes are brought about is vitamin D-dependent and involves an enhanced production of 1,25dihydroxycholecalciferol $\left(1,25(\mathrm{OH})_{2} \mathrm{D}_{3}\right)$.

The metabolic interrelationship between calcium ions and phosphate ions has been extensively studied and it is well established that $\mathrm{Ca}^{2+}$ and $\mathrm{H}_{2} \mathrm{PO}_{4}^{-}$have a marked influence on the gastrointestinal absorption, excretion and skeletal utilization of each other (Nicolaysen et al. 1953). The close relationship between the skeleton and the metabolism of $\mathrm{Ca}$ and $\mathrm{P}$ was demonstrated by the findings that the amounts of $\mathrm{Ca}$ and $\mathrm{P}$ in the skeleton decrease when a very-low-P diet was fed (Kemm, 1976) and that $P$ retention is controlled by the rate of $\mathrm{Ca}$ retention which is itself directly related to $\mathrm{Ca}$ absorption (Braithwaite, 1975).

With the exception of one report, the absorption of $\mathrm{Ca}$ from the digestive tract of ruminants appears to follow a general pattern similar to that shown by non-ruminants. Since ruminant diets generally contain a high proportion of roughage, the supply of dietary $\mathrm{Ca}$ is usually adequate but dietary $P$ is often limiting. Although it is no longer believed that $P$ is essential for $\mathrm{Ca}$ transport across the wall of the small intestine, and indeed Morrissey \& Wasserman (1971) have shown that dietary $P$ deficiency led to an increase in the efficiency of absorption of $\mathrm{Ca}$ from the duodenum of chicks, there is one report that the rate of $\mathrm{Ca}$ absorption in sheep is reduced if their $\mathrm{P}$ intake is deficient (Young et al. 1966).

The present investigations were undertaken to study the adaptation of $\mathrm{Ca}$ absorption by sheep in response to feeding a diet low in either $\mathrm{Ca}$ or $\mathrm{P}$ and to monitor the effects of these 
Table 1. The composition $(\mathrm{g} / \mathrm{kg})$ of the control diet prepared

\begin{tabular}{lc}
\hline \hline Ground maize & 480 \\
Beet molasses & 100 \\
Maize flour & 100 \\
Wheat straw & 283 \\
Urea & 15 \\
Sodium chloride with trace elements* & 5 \\
Retinol & $790 \mu \mathrm{g} / \mathrm{kg}$ diet \\
Cholecalciferol & $8.25 \mu \mathrm{g} / \mathrm{kg}$ diet \\
Calcium carbonate & 9 \\
Sodium dihydrogen phosphate dihydrate & 8 \\
Calcium & 4.9 \\
Phosphorus $\}^{\text {on dry matter }}$ basis & 3.8 \\
\hline
\end{tabular}

* Contained $(\mathrm{mg} / \mathrm{g})$ not less than: 965 sodium chloride, 2 manganese, 1.6 iron, 0.33 copper, $0 \cdot 1$ cobalt, 0.07 iodine, 0.05 zinc.

diets on the plasma concentration of $1,25(\mathrm{OH})_{2} \mathrm{D}_{3}$. The response of $\mathrm{Ca}$ absorption to $1,25(\mathrm{OH})_{2} \mathrm{D}_{3}$, either exogenous or endogenous (in response to hypocalcaemia induced with EDTA), has also been studied in the sheep.

\section{EXPERIMENTAL}

Five adult sheep, one lamb ( 8 months) and one adult goat were used for this work. The composition of the prepared control diet used in absorption experiments is shown in Table 1. All adult sheep weighed approximately $50 \mathrm{~kg}$. Four sheep were prepared with a Thiry-Vella loop of jejunum $2 \mathrm{~m}$ in length, the proximal end of which was $2 \mathrm{~m}$ from the pylorus. The absorptive capacity of these loops was maintained by regular perfusion with a nutrient solution according to Fox et al. (1978). The rate of absorption of Ca varied from loop to loop, tending to be greater in that prepared in the lamb (lamb no. 131). In this animal net $\mathrm{Ca}$ absorption rate was usually measured in five periods of $1 \mathrm{~h}$ each per working day during each experiment. The initial volume of solution used was 200 or $300 \mathrm{ml}$ and the range of composition was based on that used by Care \& van't Klooster (1965). This range included the concentrations of $\mathrm{Ca}$ and $\mathrm{P}$ found in jejunal contents of sheep fed normal diets. The unidirectional absorption rate of $\mathrm{Ca}$ was measured after the addition of ${ }^{47} \mathrm{Ca}$ to the perfusion solution to give a concentration of approximately $5 \mu \mathrm{Ci} / 1 .{ }^{51} \mathrm{Cr}$-EDTA was usually used as a non-absorbable marker for the measurement of the net water movement across the wall of the jejunal wall. This was replaced by polyethylene glycol, molecular weight $4000(3 \mathrm{~g} / 1)$, when ${ }^{47} \mathrm{Ca}$ was included in the perfusion solution because of the difficulty in measuring ${ }^{51} \mathrm{Cr}$ in the presence of ${ }^{47} \mathrm{Ca}$. Jejunal loops which absorbed $\mathrm{Ca}$ relatively slowly were recirculated with $300 \mathrm{ml}$ nutrient, electrolyte solution for a period of $5 \mathrm{~h}$ before it was changed. It was shown that there was sufficient glucose in the perfusion fluid to maintain a normal potential gradient between loop fluid and blood after not more than $5 \mathrm{~h}$ recycling of $300 \mathrm{ml}$ perfusion fluid.

The calculations of net and unidirectional transfer rates of $\mathrm{Ca}$ were made according to Care \& van't Klooster (1965).

In one sheep (sheep no. 384) a thick-walled silicone-rubber catheter was sutured into the fundus of the abomasum and maintained in place with a tightly-fitting Teflon disc through which it passed. The disc was sutured to the peritoneal surface of the abomasum. A polyvinyl catheter was introduced into a recurrent tarsal vein and filled with heparinized 
physiological saline ( $9 \mathrm{~g}$ sodium chloride $/ 1 ; 50$ units sodium heparin $/ \mathrm{ml}$ ). At 3 weeks after this surgery had been completed the sheep could be used for the measurement of unidirectional absorption rate of $\mathrm{Ca}$ from the intestinal tract by the method of Marshall (1976).

An aqueous solution of $25 \mathrm{~mm}$-calcium chloride ( $5 \mathrm{ml}$ ) containing approximately $5 \mu \mathrm{C}_{\mathrm{i}}$ ${ }^{47} \mathrm{Ca}$ was injected intravenously followed $2 \mathrm{~h}$ later by a fourfold larger amount of ${ }^{47} \mathrm{Ca}$ administered directly into the abomasum as a bolus via the abomasal catheter. Samples of blood $(5 \mathrm{ml})$ were taken at intervals of $15 \mathrm{~min}$ for the first twelve samples and of $30 \mathrm{~min}$ for the remaining samples. After centrifugation of the blood the ${ }^{47} \mathrm{Ca}$ concentrations in $3 \mathrm{ml}$ portions of plasma were measured using a sodium iodide crystal (Gamma Guard 150; Tracerlab, Weybridge).

The calculation of fractional unidirectional absorption rate of $\mathrm{Ca}$ from the plasma ${ }^{47} \mathrm{Ca}$ values was carried out by deconvolution analysis according to Marshall (1976).

Thyroparathyroidectomy (TXPTX) of an adult sheep and an adult goat was carried out after location of the parathyroid glands (Care et al. 1966). Thyroxine replacement was maintained at the rate of $5 \mathrm{mg}$ sodium L-thyroxine $/ 50 \mathrm{~kg}$ body-weight administered subcutaneously in arachis oil at weekly intervals. This was shown by Payne \& Chamings (1964) to be adequate for TXPTX goats.

Concentrations of $\mathrm{Ca}$ and phosphate were measured with an AutoAnalyzer (Technicon Instruments Co. Ltd, Terrytown, New York) using Technicon methods (Technicon, 1965) $\mathrm{N} 4 \mathrm{a}$ and $\mathrm{N} 4 \mathrm{~b}$, respectively. Polyethylene glycol was measured turbidometrically by the method of Hydén (1955). During EDTA infusion into a sheep the unchelated plasma Ca concentration was monitored by titration against EDTA using a semi-automatic titrator (Evans Electro Selenium, Harlow) and murexide as an indicator.

${ }^{51} \mathrm{Cr}$ was measured using a gamma ray spectrometer (Gamma Guard 150; Tracerlab, Weybridge).

$1,25(\mathrm{OH})_{2} \mathrm{D}_{3}$ was measured in samples of plasma by a modification of the method of Clemens et al. (1979). Samples of plasma were extracted twice with an equal volume of cyclohexane-ethyl acetate $(1: 1, v / v)$. The plasma extracts were concentrated under nitrogen and then applied to small columns made from glass Pasteur pipettes and filled with previously swollen Sephadex LH20. The columns were eluted with chloroform-hexane $(60: 40, v / v)$. The fraction corresponding to $1,25(\mathrm{OH})_{2} \mathrm{D}_{3}$ was evaporated to dryness under $\mathrm{N}_{2}$ and subjected to high-pressure liquid chromatography on a Zorbax Sil Column $(0.42 \times 25 \mathrm{~cm})$. Elution was with hexane-isopropanol $(90: 10, \mathrm{v} / \mathrm{v})$ at a flow rate of $2 \mathrm{ml} / \mathrm{min}$ and 70 atmos. pressure. The fraction corresponding to $1,25(\mathrm{OH})_{2} \mathrm{CC}$ was evaporated to dryness under $\mathrm{N}_{2}$ and redissolved in redistilled ethanol. Samples were then assayed using an antiserum raised by us in sheep to $1,25(\mathrm{OH})_{2} \mathrm{D}_{3}$-hemisuccinate-bovine serum albumin conjugate (Clemens et al. 1978).

\section{RESULTS}

Effect of intraluminal $\mathrm{Ca}$ concentration on the net absorption rate of Ca from a Thiry-Vella loop of jejunum

An 8-month old lamb (lamb no. 131) fed on the control diet (Table 1) was used for this experiment. The initial $\mathrm{Ca}$ and $\mathrm{P}$ concentrations in the perfusion solution were altered over the range $1.5-15 \mathrm{mmol} / \mathrm{l}$ in such a way as to keep the $\mathrm{Ca}: \mathrm{P}$ value at 1 and the osmolarity at $237 \mathrm{mosmol} / \mathrm{l}$. Fig. $\mathrm{l}$ shows that the net $\mathrm{Ca}$ absorption rate continued to increase with initial intraluminal $\mathrm{Ca}$ concentration over the range of $\mathrm{Ca}$ concentration used.

\section{Level of dietary $\mathrm{Ca}$ and the net absorption rate of $\mathrm{Ca}$}

Lamb no. 131 was fed on the control diet $(\mathrm{Ca} 4.9 \mathrm{~g} / \mathrm{kg} ; \mathrm{P} 3.8 \mathrm{~g} / \mathrm{kg}$ ) for approximately 4 weeks and was then transferred to the same daily weight of the low-Ca diet $(\mathrm{Ca} 1.3 \mathrm{~g} / \mathrm{kg}$; 


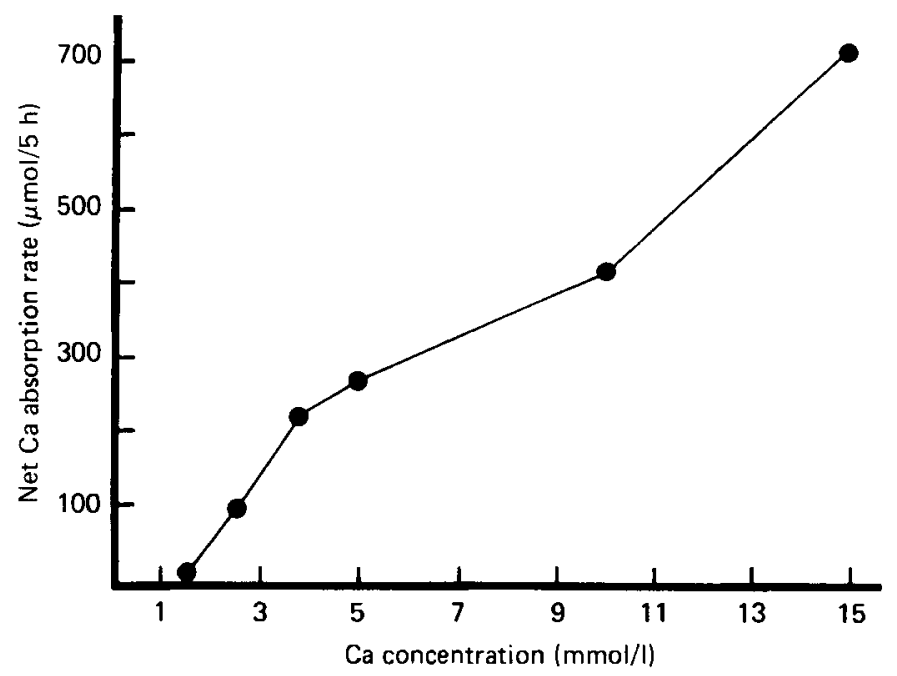

Fig. 1. The relationship between the net absorption rate of calcium $(\mu \mathrm{mol} / 5 \mathrm{~h}$ ) from the contents of a Thiry-Vella loop of jejunum in lamb no. 131 and the $\mathrm{Ca}$ concentration in the jejunal perfusion fluid (mmol/l).

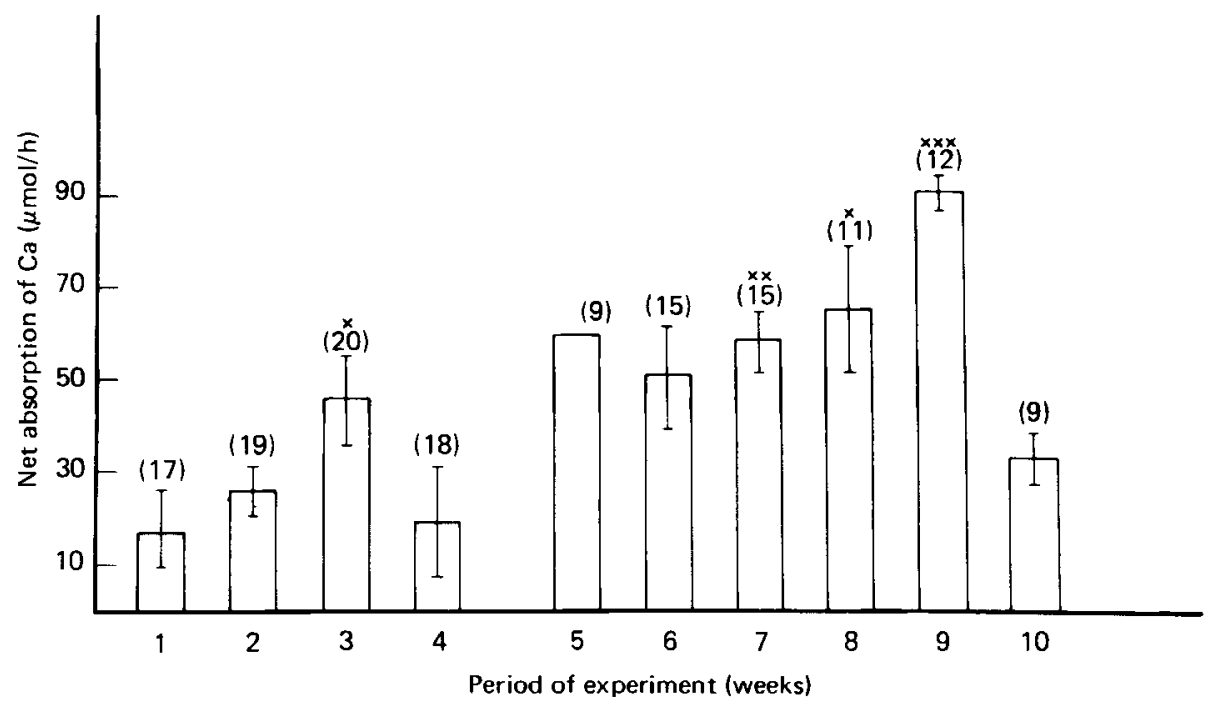

Fig. 2. Adaptation of the net rate of calcium absorption from a loop of jejunum perfused in situ to changes in the dietary intake of $\mathrm{Ca}$ by lamb no. 131 . Week $1, \mathrm{Ca} 4.9 \mathrm{~g} / \mathrm{kg}$; weeks $2-3, \mathrm{Ca} 1.3 \mathrm{~g} / \mathrm{kg}$; week 4 , $\mathrm{Ca} 4.9 \mathrm{~g} / \mathrm{kg}$; weeks $5-8$ inclusive, Ca $0.6 \mathrm{~g} / \mathrm{kg}$; weeks $9-10, \mathrm{Ca} 4.9 \mathrm{~g} / \mathrm{kg}$. Other constituents of these diets remained unchanged. Mean values with their standard errors represented by vertical bars. Values were statistically significantly different from those from the preceding normal-Ca diet: ${ }^{*} P<0.025$, ** $P<0.01,{ }^{* * *} P<0.001$ (Student's $t$ test).

P $3.8 \mathrm{~g} / \mathrm{kg}$ ). The composition of this diet was the same as that of the control diet with the omission of calcium carbonate. The perfusion solution used throughout this experiment contained $3 \mathrm{mmol} \mathrm{Ca} / \mathrm{l}$ and $2 \mathrm{mmol} \mathrm{P} / \mathrm{l}$. The change in dietary $\mathrm{Ca}$ caused a gradual increase in the net absorption rate of $\mathrm{Ca}$ which became significant during the second week of feeding the low-Ca diet (Fig. 2). The animal was then returned to the control diet for $9 \mathrm{~d}$ during which time the net absorption rate of $\mathrm{Ca}$ was restored to the original control level. During 
the next $24 \mathrm{~d}$ the sheep was fed on a similar diet in which beet molasses was replaced by more ground maize to reduce further the $\mathrm{Ca}$ content $(\mathrm{Ca} 0.6 \mathrm{~g} / \mathrm{kg} ; \mathrm{P} 3.4 \mathrm{~g} / \mathrm{kg}$ ). There was a rapid rise in the absorption rate of $\mathrm{Ca}$ which became significant by the third week of dietary $\mathrm{Ca}$ depletion. This increase in efficiency of $\mathrm{Ca}$ absorption persisted into the first week of dietary $\mathrm{Ca}$ repletion but during the second week of feeding the $\mathrm{Ca}$-replete diet the net $\mathrm{Ca}$ absorption rate was restored to a level which was not significantly different from that found at the start of the experiment.

The mechanism of this effect was investigated by measuring the effect on the plasma concentration of $1,25(\mathrm{OH})_{2} \mathrm{D}_{3}$ caused by changing the diet of an adult sheep from one which contained $4.9 \mathrm{~g} \mathrm{Ca} / \mathrm{kg}$ to one containing $1.3 \mathrm{~g} \mathrm{Ca} / \mathrm{kg}$. The plasma level of $1,25(\mathrm{OH})_{2} \mathrm{D}_{3}$ was found to increase from $74 \mathrm{pg} / \mathrm{ml}$ to $102 \mathrm{pg} / \mathrm{ml}$ after 2 weeks of Ca depletion.

\section{Effect of calcium chelation produced by an intravenous infusion of EDTA on the net absorption rate of $\mathrm{Ca}$}

The net and unidirectional rates of absorption of $\mathrm{Ca}$ from the jejunal loop of lamb no. 131 were measured when the lamb was fed on the control diet $(\mathrm{Ca} 4.9 \mathrm{~g} / \mathrm{kg} ; \mathrm{P} 3.8 \mathrm{~g} / \mathrm{kg})$. At $4 \mathrm{~d}$ after the unidirectional rate of $\mathrm{Ca}$ absorption had been established, the lamb was infused intravenously with EDTA $(44 \mathrm{~g} / \mathrm{l})$ at the rate of $4.2 \mathrm{~g} / \mathrm{h}$ for $1.2 \mathrm{~h}$, followed by $0.42 \mathrm{~g} / \mathrm{h}$ for 5-15 h. The net absorption rate of $\mathrm{Ca}$ from a perfusion solution containing $15 \mathrm{mmol} \mathrm{Ca} / \mathrm{l}$ and $15 \mathrm{mmol} \mathrm{P} / 1$ was measured during five $1 \mathrm{~h}$ periods each day. The unidirectional rate of Ca absorption was again measured $3 \mathrm{~d}$ after the start of the infusion of EDTA.

The initial rate of net $\mathrm{Ca}$ absorption was only $14 \mu \mathrm{mol} / \mathrm{h}$. This increased gradually to reach a maximum $(537 \mu \mathrm{mol} / \mathrm{h})$ on the third day after the start of the EDTA infusion and then fell to $90 \mu \mathrm{mol} / \mathrm{h}$ by the fifth day after the start of the EDTA and to $29 \mu \mathrm{mol} / \mathrm{h}$ by the seventh day. Similarly, the fractional unidirectional rate of $\mathrm{Ca}$ absorption increased from $0.027 / \mathrm{h}$ before the EDTA to $0.227 / \mathrm{h} 3 \mathrm{~d}$ after the start of the infusion of EDTA. The unchelated $\mathrm{Ca}$ concentration in plasma was reduced from $2.58 \mathrm{mmol} / 1$ to $1.80 \mathrm{mmol} / 1$ after the first $3.5 \mathrm{~h}$ administration of EDTA.

An adult sheep (sheep no. 312) was fed on the same control diet and measurements made of the net $\mathrm{Ca}$ absorption rate from a solution containing $15 \mathrm{mmol} \mathrm{Ca} / 1$ and $15 \mathrm{mmol} \mathrm{P} / \mathrm{l}$ which was used to perfuse its Thiry-Vella loop of jejunum for five periods of $1 \mathrm{~h}$ daily. The mean ( $\pm \mathrm{SE}$ ) rate of $\mathrm{Ca}$ absorption was $60 \pm 10(n 4) \mu \mathrm{mol} / \mathrm{h}$. EDTA was then infused intravenously at the rate of $0.53 \mathrm{~g} / \mathrm{h}$ for $48 \mathrm{~h}$ and the measurement of net Ca absorption rate continued. There was a significant $(P<0.01)$ increase in this absorption rate on the second day of EDTA infusion to $190 \mu \mathrm{mol} / \mathrm{h}$. At this time the appetite of the sheep became depressed. The decrease in the daily consumption of food was accompanied by a fall in the net $\mathrm{Ca}$ absorption rate. Both these rates were undetectable by the $3-4$ th $\mathrm{d}$ after the start of infusion of disodium EDTA. Appetite and $\mathrm{Ca}$ absorption rate were monitored during the next $7 \mathrm{~d}$ when it was found that both were restored to their normal levels by the tenth day after the end of the EDTA infusion.

\section{The addition of $1 \alpha-(\mathrm{OH}) \mathrm{D}_{3}$ to the perfusion solution and its effect on the net absorption rate of $\mathrm{Ca}$}

An adult sheep with an isolated Thiry-Vella loop of jejunum was fed on a commercial diet based on dried grass and barley containing $7.8 \mathrm{~g} \mathrm{Ca} / \mathrm{kg}$ and $4.3 \mathrm{~g} \mathrm{P} / \mathrm{kg}$. The loop was perfused with a solution in which the concentrations of $\mathrm{Ca}$ and $\mathrm{P}$ were both $5 \mathrm{mmol} / \mathrm{l}$. Because of the low rates of $\mathrm{Ca}$ absorption from this particular jejunal loop each period of absorption measurement was $5 \mathrm{~h}$. During the first week of the experiment the rate of net calcium absorption was $60-110 \mu \mathrm{mol} / \mathrm{h}$. 1 $1 \alpha$-hydroxycholecalciferol $\left(1 \alpha-(\mathrm{OH}) \mathrm{D}_{3}\right)$, a synthetic analogue of $1,25(\mathrm{OH})_{2} \mathrm{D}_{3}$, was then added to the perfusion solution to give an 


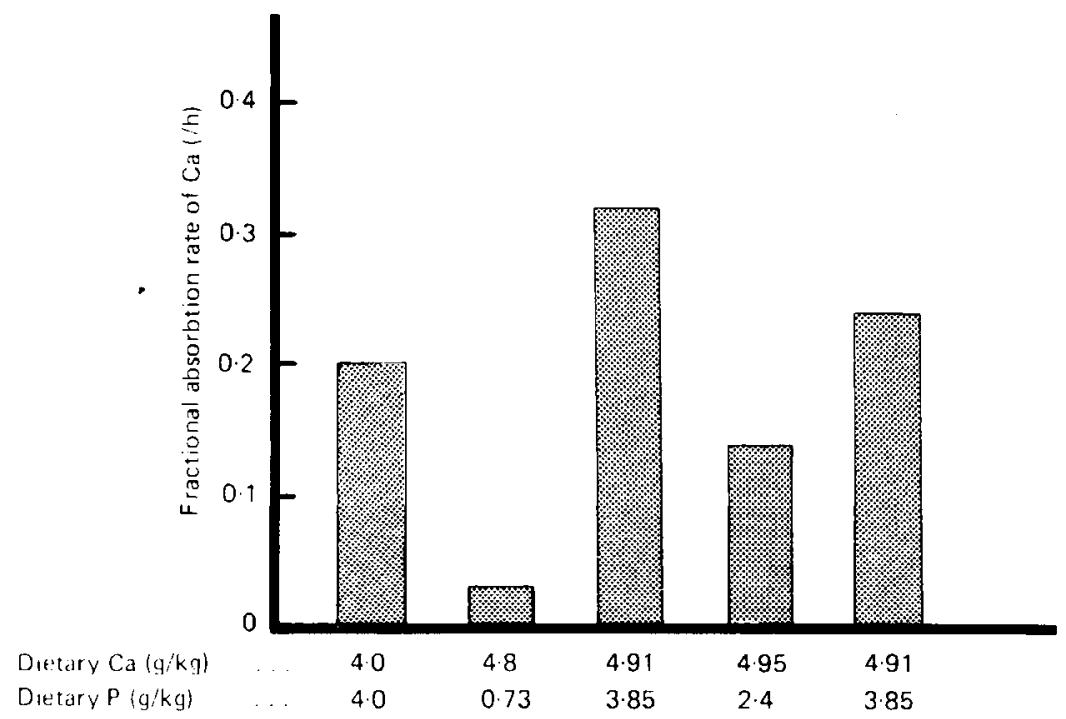

Fig. 3. Effect of the level of dietary phosphorus $(\mathrm{g} / \mathrm{kg})$ on the unidirectional fractional absorption rate of calcium $(/ \mathrm{h})$ from the intestine of adult sheep no. 384.

initial concentration of $3 \mu \mathrm{g} / \mathrm{l}$ and the loop perfused for $5 \mathrm{~h}$. This procedure was repeated on each of the next $2 \mathrm{~d}$.

There was no effect of the added $1 \alpha-(\mathrm{OH}) \mathrm{D}_{3}$ on the first day of its addition but on the second day the net $\mathrm{Ca}$ absorption rate had increased to $230 \mu \mathrm{mol} / \mathrm{h}$ and on the third day to $180 \mu \mathrm{mol} / \mathrm{h}$. By the fourth day following the last addition of $1 \alpha-(\mathrm{OH}) \mathrm{D}_{3}$ the net absorption rate of $\mathrm{Ca}$ had returned to the basal level.

The effect of level of dietary $P$ on the efficiency of $\mathrm{Ca}$ absorption

An adult sheep (sheep no. 240) with a Thiry-Vella loop of jejunum was fed for 3 weeks the control diet, normal with respect to $\mathrm{Ca}(4.9 \mathrm{~g} / \mathrm{kg})$ and $\mathrm{P}(3.8 \mathrm{~g} / \mathrm{kg})$. The net absorption rate of $\mathrm{Ca}$ from the jejunal loop was measured during five periods of $1 \mathrm{~h}$ on five consecutive days during the last week. The perfusion solution contained $13 \mathrm{mmol} \mathrm{Ca} / \mathrm{l}$ and $5 \mathrm{mmol} \mathrm{P} / \mathrm{l}$. The sheep was then transferred to a similar diet except that it was lower in $P(2 \cdot 4 \mathrm{~g} / \mathrm{kg})$. This moderately-low-P diet was fed for a further period of 2 weeks during which time the net absorption rate of $\mathrm{Ca}$ from the loop of jejunum was measured.

During the period of adequate $\mathrm{P}$ intake the mean $( \pm \mathrm{SE})$ absorption rate of $\mathrm{Ca}$ was $121.4 \pm 11.9(n 22) \mu \mathrm{mol} / \mathrm{h}$. The absorption rate tended to fall $(92 \pm 16.9(n 24) \mu \mathrm{mol} / \mathrm{h})$ during the first week in which the low-P diet was fed and the further decrease to $9 \cdot 4 \pm 17.9$ $(n 20)$ which took place during the second week of $P$ depletion was significant $(P<0 \cdot 01)$.

Adult sheep (sheep no. 384) was fed in turn four levels of dietary phosphorus. The levels of $P$ used were $0 \cdot 7,2.4,3.8$ and $4.0 \mathrm{~g} / \mathrm{kg}$. The sheep was allowed $27-34 \mathrm{~d}$ to adapt to each experimental diet before the unidirectional absorption rate of $\mathrm{Ca}$ from the intestinal tract was measured.

Fig. 3 shows that as $\mathrm{P}$ depletion deepens there is a reduction in the fractional unidirectional absorption rate of $\mathrm{Ca}$. For example, an adequate $\mathrm{P}$ diet $(4 \mathrm{~g} \mathrm{P} / \mathrm{kg})$ was associated with a fractional unidirectional absorption rate of $\mathrm{Ca}$ of $0 \cdot 2 / \mathrm{h}$ whereas after $27 \mathrm{~d}$ during which a diet containing only $0.73 \mathrm{~g} \mathrm{P} / \mathrm{kg}$ was fed, the fractional absorption rate of $\mathrm{Ca}$ was only 0.03 . 
Table 2. Changes in plasma concentrations of calcium, inorganic phosphate and $1,25(\mathrm{OH})_{2} \mathrm{D}_{3}$ associated with dietary phosphorus depletion

\begin{tabular}{|c|c|c|c|c|c|c|c|}
\hline \multirow[b]{2}{*}{$\begin{array}{c}\text { Dietary } P \\
(\mathrm{~g} / \mathrm{kg})\end{array}$} & \multirow{2}{*}{$\begin{array}{l}\text { Period of } \\
\text { treatment } \\
\text { (weeks) }\end{array}$} & \multicolumn{2}{|c|}{$\mathrm{Ca}(\mathrm{mmol} / \mathrm{l})$} & \multicolumn{2}{|c|}{ Phosphate (mmol/l) } & \multicolumn{2}{|c|}{$1,25(\mathrm{OH})_{2} \mathrm{D}_{3}(\mathrm{pg} / \mathrm{ml})$} \\
\hline & & $\begin{array}{c}\text { TXPTX } \\
\text { Sheep }\end{array}$ & $\begin{array}{c}\text { TXPTX } \\
\text { Goat }\end{array}$ & $\begin{array}{c}\text { TXPTX } \\
\text { Sheep }\end{array}$ & $\begin{array}{c}\text { TXPTX } \\
\text { Goat }\end{array}$ & $\begin{array}{c}\text { TXPTX } \\
\text { Sheep }\end{array}$ & $\begin{array}{c}\text { TXPTX } \\
\text { Goat }\end{array}$ \\
\hline 3.0 & - & 1.72 & $1 \cdot 50$ & 1.79 & 0.97 & 37 & 26 \\
\hline 0.7 & 2 & 1.75 & $2 \cdot 17$ & 1.24 & 1.02 & 30 & 17 \\
\hline 0.7 & 3 & 2.03 & 1.75 & 0.63 & 0.53 & 25 & 18 \\
\hline
\end{tabular}

TXPTX, thyroparathyroidectomized.

Changes in the plasma concentation of $1,25(\mathrm{OH})_{2} \mathrm{D}_{3}$ associated with dietary $P$ depletion An adult sheep with a Thiry-Vella jejunal loop was fed an adequate-P diet $(3.0 \mathrm{~g} \mathrm{P} / \mathrm{kg}$; $3.4 \mathrm{~g}(\mathrm{Ca} / \mathrm{kg})$ and was found to have a plasma concentration of $1,25(\mathrm{OH})_{2} \mathrm{D}_{3}$ of $80 \mathrm{pg} / \mathrm{ml}$. After 1 week, during which a diet was fed which was similar in composition except that it was deficient in $\mathrm{P}(0.7 \mathrm{~g} \mathrm{P} / \mathrm{kg})$, the plasma concentration of $1,25(\mathrm{OH})_{2} \mathrm{D}_{3}$ was reduced to $27 \mathrm{pg} / \mathrm{ml}$. This level remained depressed $(29 \mathrm{pg} / \mathrm{ml})$ after 2 weeks on the low-P diet when the plasma phosphate concentration had been reduced from 0.75 to $0.60 \mathrm{mmol} / \mathrm{l}$.

This experiment was repeated in a thyroparathyroidectomized (TXPTX) adult sheep and a similar adult goat both of which were given replacement thyroxine at regular intervals. When fed the adequate-P diet $(3.0 \mathrm{~g} \mathrm{P} / \mathrm{kg})$ the plasma $1,25(\mathrm{OH})_{2} \mathrm{D}_{3}$ concentration in the TXPTX sheep was $37 \mathrm{pg} / \mathrm{ml}$ (Table 2). This fell to $30 \mathrm{pg} / \mathrm{ml}$ after 2 weeks on the low-P $\operatorname{diet}(0.7 \mathrm{~g} \mathrm{P} / \mathrm{kg})$ and to $25 \mathrm{pg} / \mathrm{ml}$ after 3 weeks P depletion. Similarly, in the TXPTX goat the plasma $1,25(\mathrm{OH})_{2} \mathrm{D}_{3}$ concentration decreased from $26 \mathrm{pg} / \mathrm{ml}$ on the adequate-P diet $(3.0 \mathrm{P} / \mathrm{kg})$ to $17 \mathrm{pg} / \mathrm{ml}$ after 2 weeks on the low-P diet $(0.7 \mathrm{P} / \mathrm{kg})$ and remained at $18 \mathrm{pg} / \mathrm{ml}$ after the third week of $\mathrm{P}$ depletion. The changes in plasma $\mathrm{Ca}$ and phosphate which occurred during $\mathbf{P}$ depletion of these two animals are also shown in Table 2.

\section{DISCUSSION}

Although in the chick $\mathrm{Ca}$ absorption has been shown to involve both diffusion and active transport (Wasserman \& Taylor, 1968) no clear evidence for an active component of small intestinal $\mathrm{Ca}$ absorption in adult sheep has been found (Care \& van't Klooster, 1965; Phillipson \& Storry, 1965; Scott, 1965). The active component is relatively more important at low concentrations of $\mathrm{Ca}$ within the small intestinal lumen and would also be expected to be more evident in the young animal. The relationship obtained with lamb no. 131 shown in Fig. 1 shows some resemblance to that obtained by Wasserman \& Taylor (1968) but the comparison is not conclusive. Since this lamb was receiving an adequate $\mathrm{Ca}$ intake during this period it is probable that active absorption of Ca was depressed and that diffusion was responsible for most of the increase in $\mathrm{Ca}$ absorption which accompanied an increase in intraluminal Ca concentration.

When the dietary $\mathrm{Ca}$ intake of lamb no. 131 was reduced to approximately $25 \%$ of the normal level the rate of absorption of $\mathrm{Ca}$ from the solution used to perfuse the Thiry-Vella loop of jejunum doubled 1 week after the start of feeding the low-Ca diet. Because there is no connexion between the lumen of the jejunal loop and that of the rest of the small intestine, a rise in absorption rate of $\mathrm{Ca}$ from a solution of constant composition used to perfuse the loop indicates an increase in the absorptive efficiency of $\mathrm{Ca}$ by the jejunal mucosa. Reducing the dietary $\mathrm{Ca}$ intake still further brought about an additional increase in the 
efficiency of absorption of Ca from the duodenum (Fig. 2). This result confirms that of van't Klooster (1976) who showed that the efficiency of absorption of $\mathrm{Ca}$ from the small intestine of lactating dairy cows increased in response to a reduced intake of dietary $\mathrm{Ca}$. When this type of experiment is carried out in sheep which are neither growing, pregnant nor lactating and have been fed on a diet which provides an adequate intake of $\mathrm{Ca}$ it is difficult to demonstrate an adaptation in the efficiency of $\mathrm{Ca}$ absorption in response to a short-term reduction in $\mathrm{Ca}$ intake. It should also be noted in Fig. 2 that the high level of adapted $\mathrm{Ca}$ absorption persisted for approximately 1 week after the sheep was transferred back to the control diet with adequate $\mathrm{Ca}$ content.

This has an important application in the prevention of parturient hypocalcaemic paresis (milk fever) by dietary manipulation (Pickard, 1975; Westerhuis, 1976).

Van't Klooster (1976) also demonstrated an increase in the efficiency of Ca absorption in response to an intravenous infusion of EDTA. We have confirmed this finding using lamb no. 131 in which $0 \cdot 8-1 \cdot 2 \mathrm{~g}$ Ca was chelated by the EDTA during a period of $6-16 \mathrm{~h}$. The chelation of $2.7 \mathrm{~g} \mathrm{Ca}$ in $48 \mathrm{~h}$ in an adult sheep, fed on an adequate $\mathrm{Ca}$ intake, at first increased the efficiency of $\mathrm{Ca}$ absorption from the jejunum but as anorexia developed the rate of $\mathrm{Ca}$ absorption was also reduced. The mechanism of this parallel change in appetite and rate of $\mathrm{Ca}$ absorption is unknown but may be related to the chelation of other elements, e.g. zinc, which have been shown to affect appetite (Chesters \& Quarterman, 1970).

Adaptation to a low-Ca diet in non-ruminants is known to be caused by an increase in the circulating concentration of $1,25(\mathrm{OH})_{2} \mathrm{D}_{3}$ (Boyle et al. 1971). Thus, it was to be expected that the addition of $1 \alpha-(\mathrm{OH}) \mathrm{D}_{3}$ to the solution used to perfuse a jejunal loop should lead to an increase in the rate of absorption of $\mathrm{Ca}$. A similar response has been noted in the pig (Fox \& Care, 1979).

In non-ruminants, it is well established that a low-P diet tends to be associated with hypercalcaemia and consequent depressed secretion of parathyroid hormone. A similar hypercalcaemic effect has been observed in the sheep; this involved a rise from 2.4 to $3.2 \mathrm{mmol} \mathrm{Ca} / 1$ after 3 weeks on a low-P diet $(0.7 \mathrm{~g} \mathrm{P} / \mathrm{kg})$. Parathyroidectomy is known to reduce the circulating concentration of $1,25(\mathrm{OH})_{2} \mathrm{D}_{3}$ in non-ruminants (Hughes et al. 1975) and this has been confirmed in the sheep (Mañas-Almendros et al. 1982). In non-ruminants, despite the concomitant hypercalcaemia, a low-P diet leads to a rise in the plasma concentration of $1,25(\mathrm{OH})_{2} \mathrm{D}_{3}$ and a consequent increase in the efficiency of absorption of $\mathrm{Ca}$ from the small intestine (Hughes et al. 1975; Fox \& Care, 1978). It is apparent from the results shown in Fig. 3 that $P$ depletion of the sheep leads to a decrease in the efficiency of absorption of $\mathrm{Ca}$. This anomaly presumably results from the depressed plasma concentration of $1,25(\mathrm{OH})_{2} \mathrm{D}_{3}$, the production of which is not enhanced by the hypophosphataemia which accompanies $\mathrm{P}$ depletion. It can be seen from Table 2 that neither parathyroid hormone nor calcitonin can be involved in this phenomenon since dietary $\mathrm{P}$ deficiency was shown to bring about changes in the plasma concentrations of $\mathrm{Ca}$, phosphate and $1,25(\mathrm{OH})_{2} \mathrm{D}_{3}$ in TXPTX ruminants that are qualitatively similar to those that have been noted in intact sheep (Mañas-Almendros et al. 1982). Perhaps the enzyme involved, $25(\mathrm{OH}) \mathrm{D}_{3}-1$-hydroxylase, has a higher requirement for phosphate than does its counterpart in non-ruminants so that it is only maximally stimulated when the sheep is fed on a relatively-high-P diet and significant amounts of phosphate are excreted in the urine.

It is recognized that the total number of sheep used was small and that within-animal variation was employed to test the significance of a particular treatment. Nevertheless, the results considered together lead us to support the conclusion reached by Young et al. (1966) that $\mathrm{P}$ depletion in sheep leads to a reduction in the rate of absorption of $\mathrm{Ca}$. This effect appears to involve a reduction in the circulating concentration of $1,25(\mathrm{OH})_{2} \mathrm{D}_{3}$. 
The authors gratefully acknowledge the help of Dr J. Fox and Mr T. D. Gibson and the surgical assistance of Dr D. W. Pickard. The work was financed with the aid of a grant from the Agricultural Research Council to A.D.C. and financial support to A.M.A-H and M.M.A. was afforded by The Wellcome Trust for which grateful acknowledgements are made.

\section{REFERENCES}

Boyle, I. T., Gray, R. W. \& DeLuca, H. F. (1971). Proc. natl Acad. Sci. U.S.A. 68, 2131.

Braithwaite, G. D. (1974). Br. J. Nutr. 31, 319.

Braithwaite, G. D. (1975). Br. J. Nutr. 34, 331.

Care, A. D., Keynes, W. M. \& Duncan, T. (1966). J. Endocr. 34, 299.

Care, A. D. \& van't Klooster, A. T. (1965). J. Physiol., Lond. 177, 174.

Chesters, J. K. \& Quarterman, J. (1970). Br. J. Nutr. 24, 1061.

Clemens, T. L., Hendy, G. N., Graham, R. F., Baggiolini, E. G., Uskokovic, M. R. \& O'Riordan, J. L. H. (1978). Clin. Sci. Mol. Med. 54, 329.

Clemens, T. L., Hendy, G. N., Papapoulos, S. E., Fraher, L. J., Care, A. D. \& O'Riordan, J. L. H. (1979). Clin. Endocr. 11, 225.

Fox, J. \& Care, A. D. (1978). J. Endocr. 77, 225.

Fox, J. \& Care, A. D. (1979). J. Endocr. 82, 417.

Fox, J., Care, A. D. \& Swaminathan, R. (1978). Br. J. Nutr. 39, 431.

Fox, J., Swaminathan, R., Murray, T. M. \& Care, A. D. (1977). J. Endocr. 74, 345.

Hughes, M. R., Brumbaugh, P. F., Haussler, M. R., Wergedal, J. E. \& Baylink, D. J. (1975). Science, N.Y. 190, 578.

Hydén, S. (1955). K. LantbrHögsk. Annlr. 22, 139.

Kemm, J. R. (1976). J. Physiol., Lond. 256, 103.

Mañas-Almendros, M., Ross, R. \& Care, A. D. (1982). Q. J. exp. Physiol. (In the Press).

Marshall, D. H. (1976). In Calcium, Phosphate and Magnesium Metabolism, p. 257 [B. E. C. Nordin, editor]. Edinburgh: Churchill Livingstone.

Morrissey, R. L. \& Wasserman, R. H. (1971). Am. J. Physiol. 220, 1509.

Nicolaysen, R., Eeg-Larsen, N. \& Malm, O. J. (1953). Physiol. Rev. 33, 424.

Payne, J. M. \& Chamings, J. (1964). J. Endocr. 28, 19.

Phillipson, A. T. \& Storry, J. E. (1965). J. Physiol, Lond. 181, 130.

Pickard, D. W. (1975). Br. vet. J. 131, 744.

Scott, D. (1965). Q. Jl exp. Physiol. S0, 312.

Technicon Instruments Co. Ltd (1965). Tech. Bull. nos. N3b, N4b. Terrytown, N.Y.: Technicon Instruments Co. Ltd.

van't Klooster, A. Th. (1976). Z. Tierphysiol. Tierernähr. Futtermitt. 37, 169.

Wasserman, R. H. \& Taylor, A. N. (1968). J. biol. Chem. 243, 3987.

Westerhuis, J. H. (1976). Proc. 3rd int. Conf. Production Disease in Farm Animals, p. 119. Wageningen: Centre for Agricultural Publishing and Documentation.

Young, V. R., Richard, W. P. C., Lofgreen, G. P. \& Luick, J. R. (1966). Br. J. Nutr. 20, 783. 